\title{
Origins of serum alkaline phosphatase
}

\author{
J. M. YONG \\ From the Department of Chemical Pathology, St. George's Hospital Medical School, London
}

SYNOPSIS A very rapid method of agar gel electrophoresis on glass slides, together with a superior visualization technique employing simultaneous coupling of a hydrolysed naphthol substrate, have been developed for the identification of the tissues of origin of serum alkaline phosphatase. Combined with L-phenylalanine inhibition, specific for the intestinal enzyme, and heat inactivation, specific for the placental enzyme, the heterogeneity of serum alkaline phosphatase has been demonstrated. Normal adult serum contains predominantly liver-type alkaline phosphatase with a small but variable quantity of intestinal enzyme, and little or no bone enzyme.

In childhood and in infancy there is in addition a bone isoenzyme present, the amount gradually falling to adult levels with age. In pregnancy, the rise in serum alkaline phosphatase is due to the placental enzyme.

A study of nearly 2,000 sera has been undertaken and it is found that the bone enzyme is increased in osteoblastic bone diseases while in hepato-biliary disorders there is an increase in liver type enzyme. The main theories explaining the rise in serum alkaline phosphatase are examined.

The origin of serum alkaline phosphatase has interested many workers ever since Kay (1929) and Roberts (1930) first demonstrated that increased serum activity was found in certain bone and hepatobiliary disorders. The problem of the origin of the enzyme is intricately bound up with that of the mechanisms by which the serum activity is increased or decreased in health and in disease. It has long been realized that serum alkaline phosphatase arises from tissues rich in the enzyme (Kay, 1932). Previous attempts at identification of the tissues of origin were handicapped not only by lack of direct methods, but also by the influence of the work of Robison and his associates linking alkaline phosphatase with calcification (Robison, 1923; Robison and Soames, 1924, 1925, 1930; Robison, MacLeod, and Rosenheim, 1930; Robison and Rosenheim, 1934; Martland and Robison, 1924; Fell and Robison, 1929). The former led to theories based on indirect observations. Nearly all these theories assumed that the serum enzyme was of osseous origin.

In recent years, the realization that enzymes may exist in multiple structural forms has provided an impetus to development of techniques of separating these 'isoenzymes'. Of the large number of techniques attempted, few were found to have adequate resolving power to differentiate the various tissue-specific alkaline phosphatases(Moss, Campbell,

Received for publication;12 January 1967.
Anagnostou-Kakaras, and King, 1961 ; Boyer, 1963; Peacock, Reed, and Highsmith, 1963; Neale, Clubb, Hotchkis, and Posen, 1965).

A technique of agar gel electrophoresis has been developed in this laboratory which enables alkaline phosphatase isoenzymes to be rapidly and reliably differentiated. Extensive studies have been made on normal and pathological sera, and, in conjunction with other techniques described below, a clearer picture of the origins of serum alkaline phosphatase and of the mechanisms involved in alterations of enzyme activity in health and disease has emerged.

\section{METHODS}

AGAR GEL ELECTOPHORESIS A technique modified after Wieme (1959) using $1.1 \%$ Noble agar in $p \mathrm{H} 8.6$ barbiturate buffer on glass microscope slides was used. Very rapid electrophoresis was achieved by using a voltage gradient of 70 volts per centimetre, and cooling by pumping petrol ether (BP $40-60^{\circ} \mathrm{C}$.) into the tank and recycling through a coil immersed in dry-ice water mixture.

A $40 \mathrm{~mm}$. separation between serum albumin and $\gamma$-globulin could be thus achieved in 10 minutes.

PROTEIN STAINING Sera or tissue extracts were electrophoresed on pairs of slides, one of these being stained for proteins and the other for alkaline phosphatase.

Ponceau S, $0.5 \%$, in $3 \%$ trichloroacetic acid was used for protein staining. Afterwards the gels were eluted for two hours in three changes of distilled water to 
remove excess dye, and then dried overnight in a $37^{\circ} \mathrm{C}$. incubator.

ENZYME STAINING Alkaline phosphatase isoenzymes were visualized by a simultaneous coupling diazo reaction. The gel was immersed for 15 to 30 minutes in the following substrate at room temperature $\left(20-22^{\circ} \mathrm{C}\right)$ :

Disodium phosphate ester of 2-hydroxy naphthelene 3-carboxylic acid $4^{1}$-chloro, $6^{1}$-methyl anilide .....0.002M Diazotized 5-chloro-o-toluidine ..................0.0016M Magnesium chloride $0.005 \mathrm{M}$ Sodium carbonate-bicarbonate buffer $p \mathrm{H} 10$ $0.05 \mathrm{M}$

The alkaline phosphatase isoenzymes appeared as red bands while serum proteins were stained a very faint yellow. The positions of these isoenzymes relative to the protein fractions could thus be easily seen. After eluting as for the proteins, incubations overnight produced transparent slides.

PHENYL-ALANINE INHIBITOR 0.005M L-phenyl alanine, which specifically inhibits intestinal alkaline phosphatase (Fishman, Green, and Inglis, 1963), was incorporated into the substrates in some instances. The $\mathrm{D}$-isomer was then used as a control.

HEATING Electrophoresis was performed on sera before and after heating to $56^{\circ} \mathrm{C}$. for 30 minutes in the presence of $0.01 \mathrm{M}$ magnesium chloride (Neale et al., 1965).

TISSUE EXTRACTS Tissue for the extraction of alkaline phosphatase were obtained at necropsies on young adults dying from road traffic accidents. They were used within 24 hours or stored at $-20^{\circ} \mathrm{C}$. Adult bone was too difficult to homogenize and femurs from stillborn infants were used instead. After cutting the tissues into small pieces homogenization was performed using a Potter-Elvehjem homogenizer and the enzyme extracted by the butanol method of Morton (1954). The final aqueous extract was adjusted to about 30 to $40 \mathrm{King}$ Armstrong units of activity per $100 \mathrm{ml}$. before electrophoresis.

NEURAMINIDASE The procedure described by Robinson and Pierce (1964) was used. Electrophoretic mobilities before and after 20 hours incubation at $37^{\circ} \mathrm{C}$. with neuraminidase was compared.

\section{RESULTS}

TISSUE EXTRACTS Alkaline phosphatase from butanol extracts of intestinal mucosa, bone, and liver could be clearly differentiated from one another by agar gel electrophoresis. Intestinal mucosal alkaline phosphatase isoenzyme migrates at about the same speed as the $\gamma$-globulins of human sera. Bone extracts migrate between $\alpha_{2}$ globulin and $\beta$ globulin, while liver extracts migrate at the same speed as $\alpha_{2}$ globulins (Fig. 1). When these three
Isoenzymes

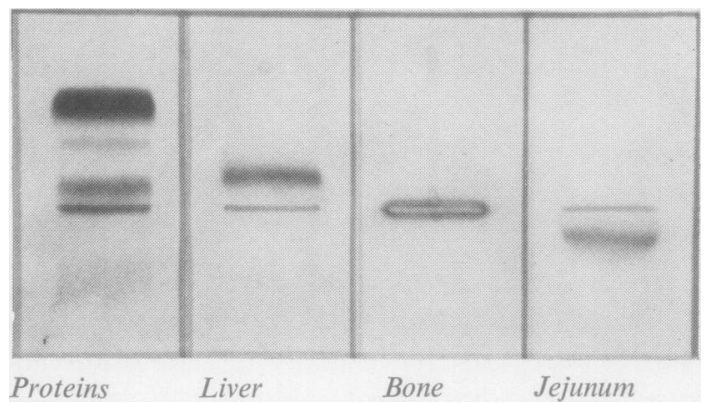

FIG. 1. Electrophoretic mobility of tissue alkaline phosphatases on agar gel compared with serum proteins at pH 8.6.

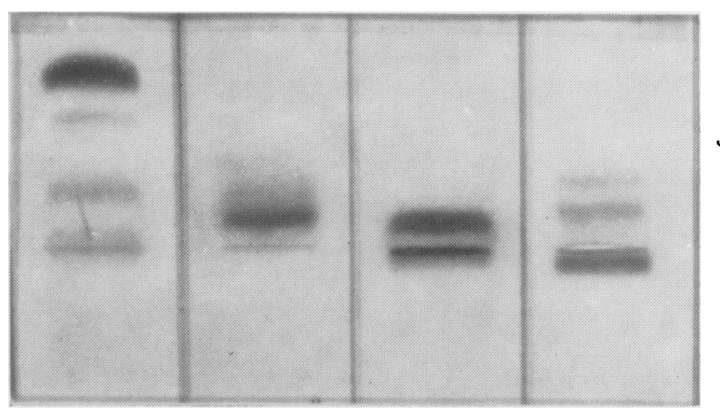

FIG. 2. Mixtures of tissue alkaline phosphatases retain their characteristic electrophoretic mobilities.

were mixed in various combinations, their characteristic electrophoretic mobilities were preserved (Fig. 2).

Thus, alkaline phosphatases of liver, bone, and intestinal mucosa are distinguishable from one another by their characteristic electrophoretic mobilities in agar gel.

EFFECT OF INHIBITOR $0.005 \mathrm{M}$ L-phenylalanine $\frac{D}{O}$ introduced into the incubation mixtures cause marked inhibition of the intestinal isoenzyme and $N$ little or no inhibition of the liver and bone iso- $N$ enzymes (Fig. 3). Some inhibition was also found with placental alkaline phosphatase.

EFFECT OF HEAT Heating for 30 minutes at $56^{\circ} \mathrm{C}$. abolished alkaline phosphatase activity of all but placental tissue extracts. This test was therefore useful for the identification of the placental enzyme.

EFFECT OF NEURAMINIDASE Incubation with neura- $\frac{\mathbb{D}}{\mathbb{Q}}$ minidase did not affect the electrophoretic mobility 0 of intestinal enzyme, but reduced those of liver and bone. 


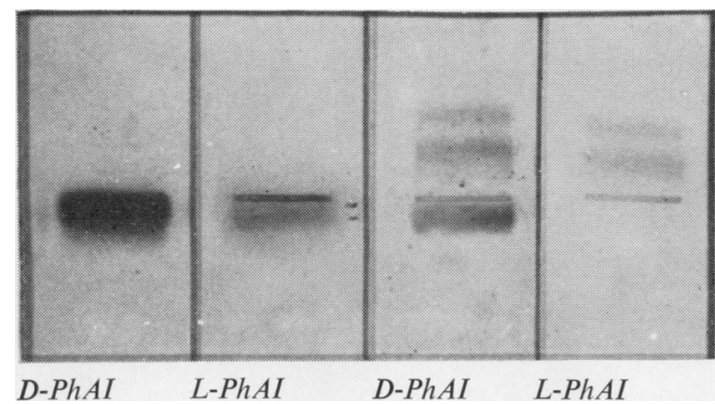

FIG. 3. Effect of 0.005M L-phenylalanine on tissue alkaline phosphatases. The intestinal isoenzyme is strongly inhibited. 0.005M D-phenylalanine is used as control in each pair of slides.

This technique thus provided further evidence of the validity of the electrophoretic technique in separating intestinal from bone and liver phosphatases. It could not, however, be used for distinguishing liver from bone alkaline phosphatase.

COMPARISON WITH OTHER TISSUES Alkaline phosphatase from stomach, duodenum, jejunum, ileum, and colon all have the same electrophoretic mobilities, migrating between $\beta$ and $\gamma$ globulins. This electrophoretic mobility is found only with one other tissue studied, the brain.

The electrophoretic mobilities of alkaline phosphatase extracted from lung tissue and the endothelium of the aorta are identical. They all migrate at the same speed as $\alpha_{2}$-globulins, are heat labile, and are not inhibited by L-phenylalanine to any degree.

Placental alkaline phosphatase migrates at a speed intermediate between $\alpha_{2}$ and $\beta$ globulins, and is thus impossible to distinguish electrophoretically from bone alkaline phosphatase. However, heating destroys the bone but not the placental enzyme.

IDENTIFICATION OF TISSUE ORIGIN By use of electrophoresis, L-phenylalanine inhibition, and heat stability, it can be seen that the tissue of origin of serum alkaline phosphatase may be inferred (Table I).

NORMAL ADULT SERA Sera from 50 healthy blood donors were subjected to electrophoresis. In all instances a single alkaline phosphatase isoenzyme, moving at the $\alpha_{2}$ globulins or at the same speed as liver isoenzyme, was found (Table II). No inhibition by L-phenylalanine was found.

Ten sera after electrophoresis were allowed prolonged staining (over one hour) and in three a second isoenzyme was found. This isoenzyme was inhibited by L-phenylalanine.
TABLE I

IDENTIFICATION OF TISSUE OF ORIGIN

\begin{tabular}{llll}
$\begin{array}{l}\text { Tissue } \\
\text { of Origin }\end{array}$ & $\begin{array}{l}\text { Electrophoretic } \\
\text { Mobility } \\
\text { Compared with } \\
\text { Serum Proteins }\end{array}$ & $\begin{array}{l}\text { L-Ph AI } \\
\text { Inhibition }\end{array}$ & $\begin{array}{l}\text { Heat } \\
\text { Stability }\end{array}$ \\
\hline Liver & $\alpha_{2}$ & 0 & \\
Aortic endothelium & $\alpha_{2}$ & 0 & Labile \\
Lung & $\alpha_{2}$ & 0 & Labile \\
Bone & $\alpha_{2} / \beta$ & 0 & Labile \\
Placenta & $\alpha_{2} / \beta$ & ++ & Labile \\
Kidney & $\alpha_{2}$ and $\beta$ & 0 & Stable \\
Intestine & $\beta / \gamma$ & +++ & Labile \\
Brain & $\beta / \gamma$ & - & Labile \\
& & & Labile
\end{tabular}

Heating at $56^{\circ} \mathrm{C}$. for 30 minutes completely abolished all enzyme activity.

These findings favour an origin in liver (or possibly lung or blood vessel) for alkaline phosphatase found in normal adult sera. In addition there may be smaller amounts of intestinal alkaline phosphatase present.

TABLE II

ORIGIN OF ALKALINE PHOSPHATASE IN NORMAL SERA

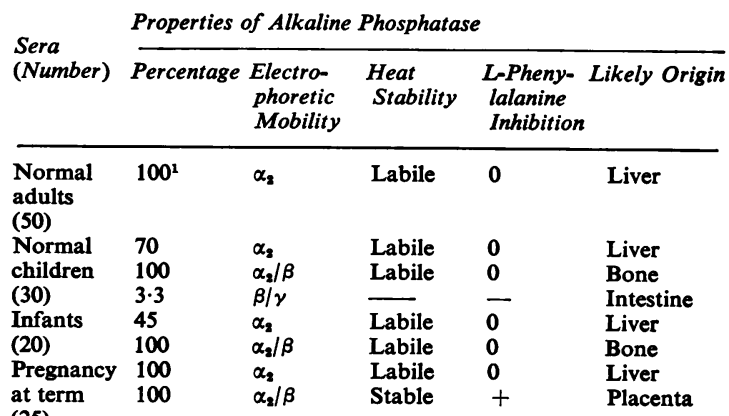
(25)

${ }^{1}$ Note that intestinal isoenzyme was found in three of 10 normal sera when prolonged incubation times were used for isoenzyme visualization

SERA FROM CHILDREN Sera from 30 normal healthy children on electrophoresis showed, in addition to the adult type of alkaline phosphatase, an isoenzyme migrating between the $\alpha_{2}$ and $\beta$ globulins. The staining intensity of this isoenzyme decreased with age, being very faint at 15 years of age. One child, aged 8, had a third isoenzyme migrating slightly faster than $\gamma$ globulin.

Heating for 30 minutes at $56^{\circ} \mathrm{C}$. destroyed virtually all alkaline phosphatase activity.

Sera obtained at birth from cord blood of 10 infants also showed two isoenzymes as for older children. The slow moving isoenzyme was, however, much more intense.

These findings favour more than one tissue of origin. In addition to the normal adult type there 
FIG. 4. Changing serum isoenzyme pattern in infancy and childhood. The high serum alkaline phosphatase activity in childhood is due to an extra isoenzyme derived from bone. The sera have been concentrated about three to four-fold by dialysis before electrophoresis.

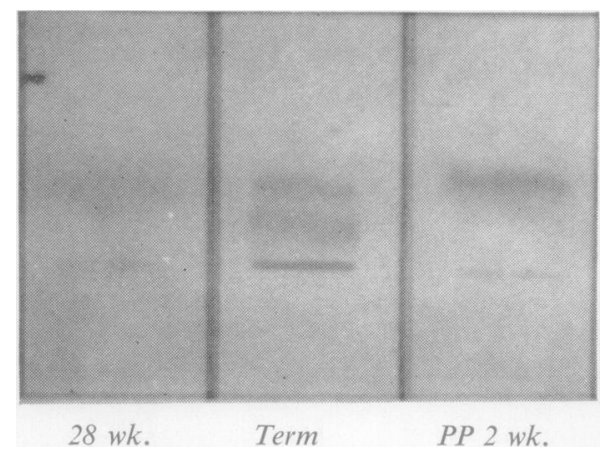

FIG. 5. Serum alkaline phosphatase isoenzymes in pregnancy. At 28 weeks a faint heat-stable placental isoenzyme is just visible. At term this isoenzyme is very prominent. At two weeks post partum this has virtually disappeared.

appears to be bone alkaline phosphatase present. In one example there was intestinal enzyme as well.

SERUM ALKALINE PHOSPHATASE IN PREGNANCY To study variations in total activity as well as qualitative changes during pregnancy, 10 patients were followed at roughly fortnightly intervals until term. The mean values have been plotted in Fig. 6 showing the total as well as the heat-stable (placental) enzyme activity.

Electrophoresis of such sera provided additional evidence of the placental origin of the enzyme (Fig. 5).

BONE DISEASE An extra isoenzyme, migrating at the same speed as bone extracts, was found in the sera of the majority $(93 \%)$ of 42 patients with osteoblastic lesions. In contrast six patients with osteoporous or burnt-out ankylosing spondylitis (Table III) showed no bone isoenzyme.
TABLE III

SERUM ALKALINE PHOSPHATASE ISOENZYMES IN BONE AND HEPATO-BILIARY DISORDERS

\begin{tabular}{|c|c|c|c|c|c|}
\hline \multirow[t]{2}{*}{ Disorder } & \multirow{2}{*}{$\begin{array}{l}\text { No. of } \\
\text { Cases }\end{array}$} & \multirow{2}{*}{$\begin{array}{l}\text { Sera } \\
\text { Analysed }\end{array}$} & \multicolumn{3}{|c|}{ Alkaline Phosphatase Isoenzyme } \\
\hline & & & Liver & Bone & Intestinal \\
\hline Bone disease & 48 & 70 & $\begin{array}{l}45 \\
(93 \cdot 8 \%)\end{array}$ & $\begin{array}{l}39 \\
(81 \cdot 3 \%)\end{array}$ & 2 \\
\hline $\begin{array}{l}\text { Biliary tract } \\
\text { disease }\end{array}$ & 68 & 130 & $\begin{array}{l}68 \\
(100 \%)\end{array}$ & $\begin{array}{l}16 \\
(23 \cdot 5 \%)\end{array}$ & $(13 \cdot 2 \%)$ \\
\hline Hepatitis & 66 & 90 & $\begin{array}{l}59 \\
(89.4 \%)\end{array}$ & $\begin{array}{l}18 \\
(24 \cdot 2 \%)\end{array}$ & $\begin{array}{l}12 \\
(18 \cdot 2 \%)\end{array}$ \\
\hline $\begin{array}{l}\text { Cirrhosis and } \\
\text { hepatic } \\
\text { infiltrations }\end{array}$ & 85 & 129 & $\begin{array}{l}85 \\
(100 \%)\end{array}$ & $\begin{array}{l}12 \\
(14 \cdot 1 \%)\end{array}$ & 6 \\
\hline
\end{tabular}

TABLE IV

DETAILED ANALYSIS OF SERA OF PATIENTS WITH BONE DISORDERS

\begin{tabular}{|c|c|c|c|c|}
\hline \multirow[t]{2}{*}{ Disorder } & \multirow{2}{*}{$\begin{array}{l}\text { No. of } \\
\text { Cases }\end{array}$} & \multicolumn{3}{|c|}{ Alkaline Phosphatase Isoenzymes } \\
\hline & & Liver & Bone & Intestinal \\
\hline Paget's disease & 12 & 11 & 10 & 0 \\
\hline $\begin{array}{l}\text { Bony metastases with } \\
\text { raised serum } \\
\text { alkaline phosphatase }\end{array}$ & 9 & 8 & 8 & 0 \\
\hline Multiple fractures & 4 & 4 & 4 & 0 \\
\hline Rickets and & 8 & 7 & 8 & 2 \\
\hline
\end{tabular}

osteomalacia

Osteogenic sarcoma

Hypertrophic

osteoarthropathy

Osteosclerosis

Osteitis fibrosa

cystica

Total (osteoblastic

disorders)

Osteoporosis

Ankylosing spondylitis 2

(inactive)

Total (bone disorders) 48

Thus, osteoblastic bone lesions give rise to a detectable bone alkaline phosphatase isoenzyme in the serum, even when the total activity is within normal limits.

HEPATO-BILIARY DISORDERS Two hundred and $\widetilde{N}$ nineteen patients with obstructive disease of the extrahepatic bile ducts, infiltrations of the liver, and hepatitis from virus infections or drugs, such as chlorpromazine, were studied by electrophoresis of the serum alkaline phosphatase levels on 349 o occasions.

All of 85 patients with hepatic infiltrations and of 68 patients with obstructive bile duct disorders showed increased liver-type alkaline phosphatase. A small number also had bone and intestinal type $\stackrel{\odot}{\mathscr{Q}}$ isoenzymes. More careful analysis of the latter $\stackrel{\unrhd}{\varrho}$ showed various associated bone disorders or multiorgan disorders such as disseminated cancer. 8 


\section{DISCUSSION}

Numerous attempts have been made in the past to elucidate the problem of the origin of serum alkaline phosphatase. Most of these attempts have met with limited success.

Bodansky (1937) found that bile salts inhibited bone and kidney phosphates but not the intestinal enzyme. He was, however, unable to come to any conclusion about the origin of human serum alkaline phosphatase. Schlamowitz prepared antibodies against various human alkaline phosphatases but cross-reactions made interpretation difficult (Schlamowitz, 1958; Schlamowitz and Bodansky, 1959). Landau and Schlamowitz (1961) utilized $\mathbf{K}_{\mathrm{m}}$ measurements without success.

Significant advances were made when L-phenylalanine, zone electrophoresis, and heat stability were utilized. Fishman and his associates (Fishman et al., 1962, 1963) showed that L-phenylalanine specifically inhibited intestinal alkaline phosphatase.

Paper electrophoresis of alkaline phosphatase was introduced by Baker and Pellegrino (1954) and by Eisfeld and Koch (1954). Other workers have since utilized starch block (Rosenberg, 1959; Keiding, 1959), agar gel (Stevenson, 1961), cellulose acetate (Korner, 1962), starch gel (Estborn, 1959), and polyacrylamide gel (Allen and Hyncik, 1963).

However, although the intestinal isoenzyme could be separated from the liver or bone isoenzymes by such techniques, the latter two could not be differentiated from one another. Further, starch gel electrophoresis, the most popular of these techniques, usually separates each tissue alkaline phosphatase into two or more isoenzymes, so that when there is more than one tissue of origin, interpretation becomes difficult.

In this laboratory, a very rapid and relatively simple technique of agar gel electrophoresis has been developed in conjunction with a superior visualization technique to enable liver, bone, intestinal, and other types of alkaline phosphatase to be clearly separated. When used in conjunction with L-phenylalanine inhibition and heat stability, the tissues of origin can be reliably made on every specimen studied.

Studies on nearly 2,000 sera have shown that serum alkaline phosphatase originates from several organs. In infants and children, two isoenzymes are found. One appears to be derived from the liver and the other from bone. The activity of the bone isoenzyme appears to be highest at birth and declines with age. This is not surprising in view of the close relationship of total serum alkaline phosphatase activity in children to the measured rate of bone growth (Clark and Beck, 1950).
In adult life there is no bone isoenzyme detected in the serum by the technique used. The liver type isoenzyme is present in the vast majority of people. Prolonged incubation with the substrate produced an intestinal isoenzyme in three of 10 sera. It is interesting to compare this with the result reported by other workers using starch gel electrophoresis and rather long incubation times. Arfors and his associates (Arfors, Beckman, and Lundin, 1963a, 1963b) have found $28 \%$ having a second slow moving isoenzyme. Beckman (1964) found it in nearly $32 \%$ of donors of blood group $\mathrm{O}$ and $\mathrm{B}$ but none in blood group $A$.

Later studies (Bamford, Harris, Luffman, Robson, and Cleghorn, 1965; Hope, 1966) have found it in between $16 \cdot 1$ and $69.2 \%$, depending on the blood group. Thus, it appears that as longer incubation times are used, the small amount of intestinal phosphatase activity present can be shown up. Significantly, while bone isoenzyme was readily detected in osteoblastic bone disorders in the present study, even prolonged incubation times failed to show it in normal adult sera. It may thus be inferred that the predominant serum alkaline phosphatase is of the liver type, with variable but small amounts of intestinal isoenzyme, and very little, if any, bone isoenzyme.

In pregnancy, the electrophoretic properties and the heat stability of the serum enzyme imply that the increase is of placental origin. These findings confirm those of McMaster, Tennant, Clubb,

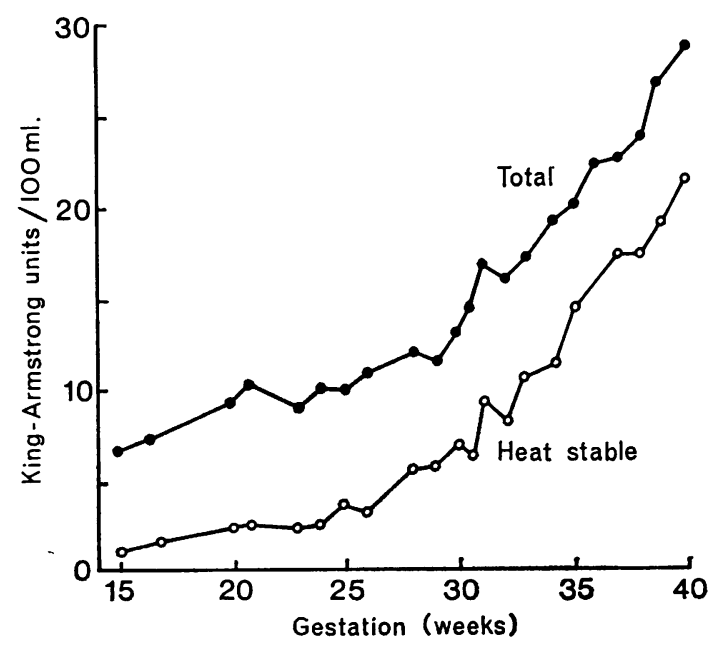

FIG. 6. Mean serum alkaline phosphatase in 10 women during the course of pregnancy. The heat-stable portion represents the placental contribution. 
Neale, and Posen (1964), who were the first to utilize the heat-stable property of placental alkaline phosphatase to study this problem, and those of Zuckerman and Sadovsky (1965) who used the same technique. The latter have also shown that placental alkaline phosphatase has a greater affinity for $\beta$-glycerophosphate than $\mathrm{p}$-nitrophene phosphate. During pregnancy, serum alkaline phosphatase shows a progressively increasing preference for $\beta$-glycerophosphate while this is not seen in patients with bone or hepatobiliary disorders (Sadovsky and Zuckerman, 1965).

The overall evidence thus leaves little doubt that the increase in serum alkaline phosphatase in pregnancy is of placental origin.

In bone disorders associated with increased osteoblastic activity there is an increase in serum alkaline phosphatase activity (Gutman, 1959). Such patients show an additional isoenzyme having the electrophoretic mobility characteristic of bone or placental isoenzyme. However, as none of the patients studied were pregnant, and the isoenzyme was found regardless of the sex of the patients, it may be safely concluded that the increase is due to the bone isoenzyme.

In hepatobiliary disorders, there is no detectable bone isoenzyme in the serum but instead the hepatic type of alkaline phosphatase is increased. This suggests that in these disorders the raised serum activity is due to increased output of the enzyme by the liver into the blood stream.

Electrophoresis of bile reveals an isoenzyme having the same electrophoretic mobility as liver type alkaline phosphatase but not bone type. Thus, the widely held theory of impaired excretion of the bone enzyme (Roberts, 1930, 1933; Armstrong, King, and Harris, 1934; Armstrong and Banting, 1935; Gutman, Olson, Gutman, and Flood, 1940; Gutman, 1959) is not supported by this evidence.

Indeed, other workers have previously found evidence which conflicted with the theory. There is often a dissociation between serum bilirubin and serum alkaline phosphatase in various liver disorders (Burke, 1950). Metastatic cancer in the liver has long been known to produce hyperphosphatasia without hyperbilirubinaemia (Meranze, Meranze, and Rothman, 1938; Ross, Iber, and Harvey, 1956; Gibbons, 1957), but the level of alkaline phosphatase does not correlate with the extent of the infiltration. Similarly a proportion of patients with hepatitis have very high serum alkaline phosphatase levels while a proportion with common bile duct obstruction have appeared normal. Gutman et al. (1940) have drawn attention to the anomaly that infants with biliary atresia usually do not have a serum alkaline phosphatase activity greater than expected for their age. This finding is, however, compatible with the hypothesis that the enzyme originates from 으 the liver. It is known that the livers of infants have

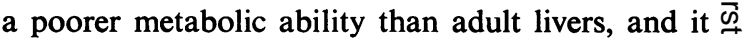
is interesting to note that liver type isoenzyme was absent in $30 \%$ of the sera of children studied in the present work.

Experiments on animals produce even stronger $\stackrel{\mathbb{Q}}{\Omega}$ evidence against the retention theory. Ligation of $\infty$ one hepatic (bile) duct produces gross elevation of $\overrightarrow{0}$ serum alkaline phosphatase but little jaundice (Freeman, Chen, and Ivy, 1938; Polin, Spellberg, $\vec{\omega}$ Teitelman, and Okumura, 1962). The bile alkaline phosphatase activity was increased, as was the enzyme content of the liver lobe drained by the $\dot{\sim}$ ligated duct (Polin et al., 1962).

Sebesta, Bradshaw, and Prockop (1964), using isolated perfused cat livers, found no increase in $\vec{V}$ alkaline phosphatase activity in the perfusate when the bile ducts were patent, but large increases were $\overrightarrow{ }$ obtained when these were occluded. This provides $气$ strong evidence that the liver is the source of the enzyme. Further, transfusion of high alkaline $\vec{\oplus}$ phosphatase blood from dogs with common bile $v$ duct stricture to normal animals resulted in high serum levels for many days, the enzyme activity only declining slowly (Freeman and Chen, 1938;

Cantarow and Miller, 1948; Dalgaard, 1951).
Clubb, Neale, and Posen (1965) have infused placental and bone alkaline phosphatase into humans and shown that the half-line in plasma was about seven days. No significant difference was found between subjects with bile duct obstruction and those without. Indeed, the disappearance rate of infused placental alkaline phosphatase from the circulation is similar to that of infused ${ }^{131}$ I albumin (Clubb et al., 1965). This behaviour is to be expected, for the molecular weight of purified alkaline $\delta$ phosphatases from various tissues has been estimated to be between 120,000 and 130,000 (Boyer, ㅇ 1963). Indeed, excretion would require a highly $D$ specialized transport system for molecules of this size.

Finally one must consider the origin of the hepatic type alkaline phosphatase found in normal adult sera in the present study.

Identical isoenzyme patterns are found with alkaline phosphatase from the endothelium, lung, $\varphi$ and choroid plexus. It is also known that in the $\Phi$ liver, endothelial cells of the portal and central $\stackrel{\mathscr{C}}{\rightarrow}$ veins are richer in this enzyme than bile ducts or $\frac{7}{7}$ liver parenchymal cells (Morrison, Karl, Schwartz, $\frac{O}{\Phi}$

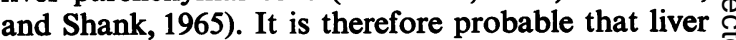
alkaline phosphatase is derived from the endothelial $\stackrel{\square}{\circledR}$ cells, and the enzyme is indistinguishable from other blood vessel endothelial alkaline phosphatase. 
There is probably a second type of alkaline phosphatase found in the biliary system. This enzyme cannot be separated from the other liver type alkaline phosphatase by the agar gel electrophoresis technique, but differences have been shown by Pope and Cooperband (1966) using starch gel electrophoresis.

Raised serum alkaline phosphatase levels in hepatobiliary disease thus would arise by increased liver synthesis of either enzyme: in conditions in which bile duct pressure is increasing the amount of bile type enzyme produced is increased, some of which finds its way into the blood plasma, while in hepatocellular disorders, such as certain cases of cirrhosis and hepatitis, or in metastatic liver disease, there is an increase in the blood vessel type of enzyme produced. In infantile livers this ability to synthesize either enzyme is rudimentary, so that bile duct atresia hardly promotes any increase in alkaline phosphatase.

My thanks are due to the British Empire Cancer Campaign for financial support and to the clinicians who allowed me to study their patients. I also wish to thank Professor N. H. Martin for his continual and inspiring help.

\section{REFERENCES}

Allen, J. M., and Hyncik, G. (1963). J. Histochem. Cytochem., 11, 169. Arfors, K. E., Beckman, L., and Lundin, L. G. (1963a). Acta genet. (Basel), 13, 89.

,,--1 (1963b). Ibid., 13, 366.

Armstrong, A. R., and Banting F. G. (1935). Canad. med. Ass. J., 33, 243.

- King, E. J., and Harris, R. I. (1934). Ibid., 31, 14.

Baker, R. W. R., and Pellegrino, C. (1954). Scand. J. clin. Lab. Invest., 6, 94.

Bamford, K. F., Harris, H., Luffman, J. E., Robson, E. B., and Cleghorn, T. E. (1965). Lancet, 1, 530.

Beckman, L. (1964). Acta genet. (Basel), 14, 286.

Bodansky, O. (1937). J. biol. Chem., 118, 341

Boyer, S. H. (1963). Ann. N.Y. Acad. Sci., 103, 938.

Burke, J. O. (1950). Gastroenterology, 16, 660.

Cantarow, A., and Miller, L. L. (1948). Amer. J. Physiol., 153, 444.

Clark, L. C., Jr., and Beck, E. (1950). J. Pediat., 36, 335.
Clubb, J. S., Neale, F. C., and Posen, S. (1965). J. Lab. clin. Med., $66,493$.

Dalgaard, J. B. (1951). Acta physiol. scand., 22, 193.

Eisfeld, G., and Koch, E. (1954) Z. ges. inn. Med., 9, 514.

Estborn, B. (1959). Nature (Lond.), 184, 1636.

Fell, H. B., and Robison, R. (1929). Biochem. J., 23, 767.

Freeman, S., and Chen, Y. P. (1938). J. biol. Chem., 123, 239.

$\longrightarrow,-$ and Ivy, A. C. (1938). Ibid., 124, 79.

Fishman, W. H., Green, S., and Inglis, N. I. (1962). Biochem. biophys. Acta, 62, 363.

- (1963). Nature (Lond.,) 198, 685.

Gibbons, T. B. (1957): J. Amer. med. Ass., 164, 22.

Gutman, A. B. (1959). Amer. J. Med., 27, 875.

—, Olson, K. B., Gutman, E. B., and Flood, C. A. (1940). J. clin. Invest., 19, 129.

Hope, R. M. (1966). Aust. J. exp. Biol. med. Sci., 44, 323.

Kay, H. D. (1929). Brit. J. exp. Path., 10, 253.

- (1932). Physiol. Rev., 12, 384.

Keiding, N. R. (1959). Scand J. clin. Lab. Invest., 11, 106.

Korner, N. H. (1962). J. clin. Path., 15, 195.

Landau, W., and Schlamowitz, M. (1961). Arch. Biochem., 95, 474.

Martland, M., and Robison, R. (1924). Biochem. J., 18, 1354.

McMaster, Y., Tennant, R., Clubb, J. S., Neale, F. C., and Posen, S. (1964). J. Obstet. Gynaec. Brit. Cwlth, 71, 735.

Meranze, D. R., Meranze, T., and Rothman, M. M. (1938). Penn. med. J., 41, 1160.

Morrison, G. R., Karl, I. E., Schwartz, R., and Shank, R. E. (1965). J. Lab. clin. Med., 65, 248.

Morton, R. K. (1954). Biochem. J., 57, 595.

Moss, D. W., Campbell, D. M., Anagnostou-Kakaras, E., and King, E. J. (1961). Ibid., 81, 441.

Neale, F. C., Clubb, J. S., Hotchkis, D., and Posen, S. (1965). J. clin. Path., 18, 359.

Peacock, A. C., Read, R. A., and Highsmith, E. M. (1963). Clin. chim. Acta, 8, 914.

Polin, S. G., Spellberg, M. A., Teitelman, L., and Okumura. M. (1962). Gastroenterology, 42, 431.

Pope, C. E., and Cooperband, S. R. (1966). Ibid., 50, 631.

Roberts. W. M. (1930). Brit. J. exp. Path., 11, 90.

- (1933). Brit. med. J., 1, 734.

Robinson, J. C., and Pierce, J. E. (1964). Nature (Lond.), 204, 472.

Robison, R. (1923). Biochem., J. 17, 286.

-, and Soames, K. M. (1924). Ibid., 18, 740. (1925). Ibid., 19, 153. (1930). Ibid., 24, 1922.

MacLeod, M., and Rosenheim, A. H. (1930). Ibid., 24, 1927. and Rosenheim, A. H. (1934). Ibid., 28, 684.

Rosenberg, I. N. (1959). J. clin. Invest., 38, 630.

Ross, R. S., Iber, F. L., and Harvey, A. McG. (1956). Amer. J. Med., $21,850$.

Sadovsky, E., and Zuckerman, H. (1965). Obstet. and Gynec., 26, 211. Schlamowitz, M. (1958). Ann. N.Y. Acad. Sci., 75, 373.

- , and Bodansky, O. (1959). J. biol. Chem., 234, 1433.

Sebesta, D. G., Bradshaw, F. J., and Prockop, D. J. (1964). Gastroenterology, 47, 166 .

Stevenson, D. E. (1961). Clin. chim. Acta, 6, 142.

Wieme, R. J. (1959). Ibid., 4, 317.

Zuckerman, H., and Sadovsky, E. (1965). Israel J. med. Sci., 1, 230. 
300 post-mortem examinations are carried out annually, a much smaller number of hospitals will be able to provide for the more advanced training requisite for the Diploma examination. The Board considers that the consultant morbid anatomist or consultant pathologist should be responsible for the training, with the assistance of his senior post-mortem room technician, and the Board will grant recognition to hospitals which are suitable for either or both forms of training.

The following is the five-year scheme of training drawn up and recommended by the Board of Education and Examination for Post-Mortem Room Technicians.

FIRST YEAR On appointment a trainee would be seconded to an area or district hospital pathologist (or morbid anatomist) for three months' introductory training and assessment of suitability at the end of the probationary period.

(a) In the preliminary training school for formal instruction in anatomy and physiology with the nurses in the block, commencing January, May, and September (eight weeks). Daily lectures to include elementary bacteriology, hygiene, and public health (two to three to four hours weekly).

(b) In the post-mortem room instruction in applied anatomy or practical anatomy, including opening and closing the body cavities and reconstruction. Instruments, use and maintenance; cleanliness, etc., in the post-mortem room; precautions against infection, injury, etc. ; the taking of specimens-bacteriological, biochemical, histological, and museum.

(c) In the laboratory: instruction as for student technicians. Elementary instruction in bacteriology, biochemistry, histology, and mounting specimens.

(d) Tutorial sessions in the post-mortem room, twice monthly (half-day release). Remainder of year at own hospital.

SECOND YEAR With the area or district hospital pathologist or morbid anatomist for four to six weeks' instruction in more advanced post-mortem procedures, including work in children and in forensic and neurological work (at special hospitals if necessary). Further experience and training in the laboratory. Tutorial sessions twice monthly. Remainder of year at own hospital.

THIRD YEAR Course of lecture-demonstrations covering the syllabus for the Certificate in Mortuary Hygiene and Technology of the Royal Institute of Public Health and Hygiene, the course to be held at a technical college or university centre or regional training centre. The course to cover winter and spring terms, once weekly for 20 weeks (minimum) with day release as necessary. Weekly tutorial sessions at a district hospital, leading to Certificate examination in April.

FOURTH OR SUBSEQUENT YEAR At selected and recognized hospital with consultant morbid anatomist for three months' training in advanced procedures, including those in children and in forensic and neurological work, either in special departments or hospitals in which all of this experience can be given. Tutorial sessions, twice monthly on half-day release, the remainder of year at own hospital.

FIFTH OR SUBSEQUENT YEAR Course of lecturedemonstrations covering the syllabus for the Diploma examination. Course held as above and also for the winter and spring terms, 20 weeks (minimum), and at more advanced level. Tutorial sessions, twice monthly (half-day release). Remainder of year at own hospital. Diploma examination in April.

From our experience of all the examinations and of the courses preparing candidates for these examinations we can point to the great advantage to all concerned of arrangements being made with a suitable technical college or university department. Pathologists can then concern themselves solely with teaching.

It is regretted that in the paper by J. M. Yong (J.Clin. Path., $1967,20,647)$ no reference was made to the work of Professor A. L. Latner and his colleagues (Hodson, A. W., Latner, A. L., and Kaine, L. (1962). Clin. chim. Acta, 7, 255) on serumalkaline phosphatase usingstarch gel electrophoresis. EDITOR, Journal of Clinical Pathology 